\title{
The Malaysian Economy: Vulnerability to Crises
}

\section{Azidin Wan Abdul Kadir}

\begin{abstract}
1 Introduction
This article examines the current strengths and remaining sources of vulnerability in Malaysia as well as the challenges for the future. It shows that the recovery in the Malaysian economy since 1998 has been due mainly to exports, resilient private consumption, and a boost in public spending, amid lower investment level. GDP growth is at present at a more moderate level of around 5-6 per cent, thereby reducing concerns of overheating, which was a main issue during the crisis. The article argues that Malaysia is unlikely to return to the rapid growth of over 9.0 per cent, as in the pre-crisis period, given the changing and more challenging global economic landscape. The increasing global competition is making it more difficult to attract FDI and expand the export markets.
\end{abstract}

The article shows that the financial sector has become more resilient following the bank mergers and the reform measures, including better risk management practices. Like other Asian countries, Malaysia has accumulated high levels of foreign reserves, which has reduced the country's vulnerability to speculative behaviour by international investors. However, an important source of vulnerability remains on the trade side. The country's trade pattern has changed slowly, with exports still fairly concentrated on electronics products. In terms of main trade partners, Malaysia has grown less sensitive to the USA and more sensitive to East Asia, especially China, in recent times. But given its high dependency on trade and the large trade flows between the USA and China, any significant slowdown in the US economy could hit Malaysia in a major way, despite recent diversification in its main export markets.

The article is divided in six sections. Following this introduction, Section 2 describes growth and external sector performance in Malaysia. Section 3 discusses the reforms in the financial sector, and Section 4 the recent trends in capital flows and developments in the capital account. Section 5 discusses vulnerabilities originating from internal imbalances, while Section 6 concludes and offers policy suggestions for reducing vulnerability.

\section{Growth performance, dynamism of exports, trade surplus and saving rates}

The Malaysian economy grew at a moderate pace of 5.4 per cent during the period 1999-2005, following a steep 7.4 per cent contraction in GDP growth in

Table 1 Unemployment rate in crisis-hit countries (\%)

\begin{tabular}{lrrrrrrrrr}
\hline (\%) & $\mathbf{1 9 9 7}$ & $\mathbf{1 9 9 8}$ & $\mathbf{1 9 9 9}$ & $\mathbf{2 0 0 0}$ & $\mathbf{2 0 0 1}$ & $\mathbf{2 0 0 2}$ & $\mathbf{2 0 0 3}$ & $\mathbf{2 0 0 4}$ & $\mathbf{2 0 0 5}$ \\
\hline Indonesia & 4.7 & 5.5 & 6.4 & 6.1 & 8.1 & 9.1 & 9.6 & 9.9 & 10.3 \\
Malaysia & 2.4 & 3.2 & 3.4 & 3.1 & 3.6 & 3.5 & 3.6 & 3.5 & 3.5 \\
Philippines & 7.9 & 9.6 & 9.4 & 10.1 & 11.1 & 11.4 & 11.3 & 11.8 & 11.4 \\
Korea & 2.6 & 6.8 & 6.3 & 4.1 & 3.8 & 3.1 & 3.4 & 3.5 & 3.7 \\
Thailand & 0.9 & 3.4 & 3.0 & 2.4 & 3.3 & 2.4 & 2.2 & 2.1 & 1.4 \\
&
\end{tabular}


Table 2 Malaysia: GDP growth by sector (\%, 1987 constant price)

\begin{tabular}{lrrrrrrrrrr}
\hline \% change & $\mathbf{1 9 9 6}$ & $\mathbf{1 9 9 7}$ & $\mathbf{1 9 9 8}$ & $\mathbf{1 9 9 9}$ & $\mathbf{2 0 0 0}$ & $\mathbf{2 0 0 1}$ & $\mathbf{2 0 0 2}$ & $\mathbf{2 0 0 3}$ & $\mathbf{2 0 0 4}$ & $\mathbf{2 0 0 5}$ \\
\hline Agriculture & 4.5 & 0.7 & -2.8 & 0.5 & 6.1 & -0.6 & 2.8 & 5.5 & 5.0 & 2.5 \\
Mining & 2.9 & 1.9 & 0.4 & 6.9 & 0.3 & -1.5 & 4.3 & 5.8 & 3.9 & 0.8 \\
Manufacturing & 18.2 & 10.1 & -13.4 & 11.7 & 18.3 & -5.9 & 4.3 & 8.6 & 9.8 & 5.1 \\
Construction & 16.2 & 10.6 & -24 & -4.4 & 0.6 & 2.1 & 2.0 & 1.5 & -1.5 & -1.6 \\
Services & 8.9 & 9.9 & -0.4 & 4.5 & 6.7 & 6.0 & 6.5 & 4.7 & 7.0 & 6.5 \\
Electricity, gas and water & 9.6 & -5.8 & 11.1 & 4.9 & 16.9 & 3.5 & 5.9 & 5.7 & 7.3 & 5.6 \\
Transport and communication & 7.4 & 11.8 & -0.3 & 4.3 & 9.8 & 8.3 & 4.1 & 5.3 & 8.4 & 6.2 \\
Wholesale and retail trade & 7.9 & 8.0 & -3.4 & 3.1 & 5.9 & 2.5 & 2.6 & 1.5 & 7.2 & 8.0 \\
Finance and business services & 17.0 & 18.9 & -1.9 & 5.9 & 7.1 & 9.5 & 14.2 & 6.3 & 7.0 & 5.7 \\
Government services & 1.7 & 8.6 & 1.1 & 6.6 & 2.0 & 4.6 & 5.3 & 8.0 & 6.9 & 7.6 \\
Other services & 7.9 & 7.0 & 1.9 & 2.7 & 4.0 & 6.9 & 4.3 & 3.3 & 4.9 & 4.9 \\
Real GDP growth & 10.0 & 7.3 & -7.4 & 6.1 & 8.9 & 0.3 & 4.4 & 5.5 & 7.2 & 5.2 \\
Source Department of Statistics, Malaysia. & & & & & & & &
\end{tabular}

1998. The growth recovery was quite bumpy as the Malaysian economy was affected by the collapse of the internet bubble in 2001. GDP growth was almost flat at 0.3 per cent in 2001, but growth rebounded thereafter when the downturn stabilised and the electronics sector recovered. From 2002-5, economic growth averaged at about 5.6 per cent, which paled in comparison to the average of more than 9.0 per cent prior to the crisis. A major reason behind the slower GDP growth was the slack in investment activity, as the private sector had gone through painful restructuring phases after the crisis. It was only in 2003 that private investment started regaining some strength. Even with the crisis, Malaysia's unemployment rate has remained low compared with its neighbours (Table 1), due to the already tight labour market prior to the crisis. The manufacturing and services sectors have been the key drivers of growth after the crisis (Table 2).

The recovery in the Malaysian economy since 1998 was generally attributed to the recovery in exports, resilient private consumption and a boost in public spending (Table 3). As a major exporter in electronics products, the rise in the demand for microchips and IT products has boosted Malaysia's exports of electronics. Since more than 50 per cent of Malaysia's exports are made-up of electronics products, total export growth has also exhibited fast growth. As a result of a weaker ringgit exchange rate, which plunged by more than 40 per cent against the US dollar in 1998, exporters of primary commodities such as petroleum, gas and palm oil have gained significantly in local currency from their US dollar export earnings.

The 1998 crisis saw many companies closing down or having to restructure their operations by disposing of their non-core activities and cutting the workforce. The crisis also revealed the over-exposure of investment in some sectors such as construction in office buildings and residential properties. Private investment has since dropped to about half the precrisis level relative to GDP, while public investment's share has increased due to the fiscal stimulus to revive the economy (Table 3). It appears that the current investment level is adequate to generate moderate growth of around 5-6 per cent, which is nearer to Malaysia's potential growth path and is more sustainable.

\subsection{Sustainability of FDI}

Owing to the rising competition from China and India, there are concerns over the sustainability of the foreign investment level. The corporate tax rate will be reduced by one percentage point per year in 
Table 3 Malaysia: Expenditure share to GDP (\%, 1987 constant price)

\begin{tabular}{|c|c|c|c|c|c|c|c|c|c|c|}
\hline$\%$ of GDP & 1996 & 1997 & 1998 & 1999 & 2000 & 2001 & 2002 & 2003 & 2004 & 2005 \\
\hline Final consumption expenditure & 59.2 & 57.6 & 56.0 & 55.8 & 56.6 & 59.5 & 60.3 & 61.6 & 62.9 & 64.8 \\
\hline Private sector & 47.8 & 46.5 & 45.0 & 43.6 & 45.3 & 46.2 & 46.3 & 46.8 & 48.2 & 50. \\
\hline Public sector & 11.4 & 11.2 & 11.0 & 12.1 & 11.3 & 13.3 & 14.0 & 14.8 & 14.7 & 14. \\
\hline Gross fixed capital formation & 48.4 & 49.2 & 30.3 & 26.7 & 30.8 & 29.8 & 28.7 & 27.9 & 26.9 & 26 \\
\hline Private sector & 35.6 & 36.3 & 17.5 & 12.7 & 15.5 & 12.4 & 10.1 & 9.6 & 11.6 & 12 \\
\hline Public sector & 12.8 & 12.9 & 12.7 & 14.0 & 15.3 & 17.5 & 18.6 & 18.4 & 15.2 & 14. \\
\hline Exports of goods and services & 96.5 & 94.8 & 102.8 & 109.6 & 116.9 & 107.8 & 107.9 & 108.2 & 117.3 & 121 \\
\hline Imports of goods and services & 102.9 & 101.5 & 89.0 & 92.7 & 105.9 & 96.5 & 98.4 & 97.2 & 109.4 & 1 \\
\hline Net export & -6.5 & -6.7 & 13.8 & 16.9 & 11.0 & 11.3 & 9.6 & 11.0 & 7.9 & \\
\hline
\end{tabular}

Source Department of Statistics, Malaysia.

2007 and 2008, to 26 per cent, as a measure to enhance Malaysia's attractiveness to foreign direct investment (FDI). The government is taking measures to diversify the economy further and promote new investments in sectors that have good growth prospects, such as 'halal' food products, bio-tech, IT services and Islamic finance. Recent initiatives to attract foreign investment include allowing a 49 per cent foreign equity stake in Islamic banks and removing limits on foreign property loans. In a major development project in southern Johor, a southern Malaysian state bordering Singapore, foreign firms are allowed 100 per cent ownership in selected services sectors, are given freehand to seek global financing and hire foreign workers. Though confined to a limited area, this is seen as an unprecedented bold move to tempt foreign investors.

During the period 2000-5, the Malaysian economy grew by 5.2 per cent (Table 4). According to the government's five-year plan report, the latest being the Ninth Malaysia Plan (9MP) report covering the period 2006-10 (Economic Planning Unit 2006), the Malaysian economy is targeted to grow at an average rate of 6.0 per annum. This medium-term growth is based on estimates derived from a Cobb-Douglas production function. The respective contributions of major factors, essentially labour, capital and total factor productivity (TFP) are worked out. If efforts to raise TFP through human capital development and R\&D activities do not materialise, the GDP growth rate could be lower than expected.
The 9MP aims to raise the value-added content of the economy while not forgetting the socioeconomic programmes to lift the quality of life of Malaysians. The private finance initiatives (PFI) announced in the 9MP will provide opportunities for the private sector to participate in development projects. The 9MP is seen as the 'National Mission' that will provide the framework for the nation's development policies in the next 15 years, to meet the goals of Vision 2020. Another major development plan that was unveiled to chart the course of the Malaysian economy over the medium and long-term is the Third Industrial Master Plan (IMP3) 2006-20. It presents strategic directions in enhancing the competitiveness of the manufacturing and services sectors under a backdrop of an increasingly competitive global landscape. It is critical that the plans are effectively implemented to meet the growth target, barring major disruptions from abroad.

The private sector will continue to be the key driver to Malaysia's growth, with the public sector complementing and facilitating the process. $A$ recent news article reported that the government had spent more than RM11 billion to take over or rescue seven ailing privatised projects in the past five years (New Straits Times, 14 December 2006). These failed projects are mainly infrastructure projects that will only generate returns over the long term. This affair also suggests that the private sector is still not totally healed as it struggles to get rid of debts and in extreme cases, is bailed out by the government. Due to budget limitations, the government can only 
Table 4 Malaysia: GDP growth by expenditure (\%, 1987 constant price)

\begin{tabular}{lrrrrrrrrrr}
\hline \% change & $\mathbf{1 9 9 6}$ & $\mathbf{1 9 9 7}$ & $\mathbf{1 9 9 8}$ & $\mathbf{1 9 9 9}$ & $\mathbf{2 0 0 0}$ & $\mathbf{2 0 0 1}$ & $\mathbf{2 0 0 2}$ & $\mathbf{2 0 0 3}$ & $\mathbf{2 0 0 4} \mathbf{2 0 0 5}$ \\
\hline Final consumption expenditure & 5.6 & 4.6 & -10.0 & \multicolumn{1}{c}{5.7} & 10.5 & 5.4 & 5.8 & 7.7 & 9.5 & 8.3 \\
Private sector & 6.9 & 4.3 & -10.2 & 2.9 & 13.0 & 2.4 & 4.4 & 6.6 & 10.5 & 9.2 \\
Public sector & 0.7 & 5.7 & -8.9 & 17.1 & 1.6 & 17.3 & 10.4 & 11.4 & 6.2 & 5.4 \\
Gross fixed capital formation & 8.2 & 9.2 & -43.0 & -6.5 & 25.7 & -2.8 & 0.3 & 2.7 & 3.1 & 4.7 \\
Private sector & 11.3 & 9.4 & -55.2 & -23.1 & 32.6 & -19.9 & -15.1 & 0.4 & 30.2 & 8.5 \\
Public sector & 0.5 & 8.4 & -8.4 & 16.3 & 19.4 & 14.5 & 11.2 & 3.9 & -11.0 & 1.9 \\
Exports of goods and services & 9.2 & 5.5 & 0.5 & 13.2 & 16.1 & -7.5 & 4.5 & 5.7 & 16.3 & 8.6 \\
Imports of goods and services & 4.9 & 5.8 & -18.8 & 10.6 & 24.4 & -8.6 & 6.3 & 4.2 & 20.7 & 8.0 \\
Net Export & -34.1 & 10.8 & -291.6 & 29.9 & -29.5 & 3.1 & -11.4 & 20.7 & -22.4 & 16.7 \\
Real GDP growth & 10.0 & 7.3 & -7.4 & 6.1 & 8.9 & 0.3 & 4.4 & 5.5 & 7.2 & 5.2 \\
Source Department of Statistics, Malaysia. & & & & & & & &
\end{tabular}

salvage projects of public interest that are still viable under proper management. To foster and facilitate private sector growth, measures adopted have included improving the government delivery system, giving tax incentives, modernising the agriculture sector, identifying and promoting new sources of growth, and uplifting the quality of human capital. In addition, the government has initiated the National Small and Medium Enterprises (SME) Development Blueprint, which has outlined the objectives, strategies and action plans to accelerate the development of the SMEs in the country.

\subsection{Strong reliance on foreign trade}

The Malaysian economy is highly dependent on trade, with trade-to-GDP ratio reaching about 200 per cent since the late 1990s. This means that the economy remains vulnerable to the global business cycle, particularly the growth performance in developed countries that are Malaysia's main export markets. The traditional top four major markets for Malaysia's exports in 2005 were USA (19.7 per cent), Europe (11.7 per cent), Japan (9.4 per cent) and Singapore (15.6 per cent). Exports to Singapore are not all meant for the local market and could possibly reach other developed countries as their final destinations. China and India are increasingly becoming important export markets for Malaysia. China's share has increased from 2.4 per cent in 1996 to 6.6 per cent in 2005, as a result of an average export growth of 25.0 per cent per year to China (Table 6). Over time, Malaysia's direction of exports has not structurally changed much in terms of shares, except for a few notable countries such as China and India.

Manufactured exports continue to be Malaysia's main export item. The large share of electrical and electronics (E\&E) products at 53.0 per cent of total exports in 2005 (Table 5) is a source of vulnerability to export performance and economic growth. Export growth is significantly affected by the movements in the global electronics cycle. This was seen in 2001 when the internet market crashed, which resulted in total exports falling by 10.6 per cent. Imports fell by 10.3 per cent because a large share of imports was intermediate inputs for the E\&E sector. Nonetheless, some export diversification has taken place, with agriculture and mining making up 7.0 per cent and 9.8 per cent of exports in 2005 , respectively, thus partly compensating for weaknesses arising from a down-cycle in electronics. Resource-based industries such as rubber and petroleum products industries can also provide a cushion to the economy when the electronics sector turns unfavourable. On account of higher oil and gas prices, the share of mining in exports increased from 6.4 per cent in 1996 to 9.8 per cent in 2005.

\section{Direction of exports}

The standard policy instruments in dealing with an external slowdown are mainly through the coordination of fiscal and monetary policies. A fiscal 


\begin{tabular}{|c|c|c|c|c|c|}
\hline \multicolumn{6}{|l|}{ Table 5 Export composition } \\
\hline & \multicolumn{2}{|c|}{ Exports (1996) } & \multicolumn{2}{|c|}{ Exports (2005) } & \multirow{2}{*}{$\begin{array}{l}\text { Average } \\
\% \text { growth }\end{array}$} \\
\hline & RM million & $\%$ share & RM million & $\%$ share & \\
\hline $\begin{array}{l}\text { Manufactured } \\
\text { of which: }\end{array}$ & 158,435 & 80.5 & 429,873 & 80.5 & 11.7 \\
\hline Electrical and electronics & 104,191 & 53.0 & 282,779 & 53.0 & 11.7 \\
\hline Electronics & 35,233 & 17.9 & 208,232 & 39.0 & 21.8 \\
\hline Electrical & 68,958 & 35.1 & 74,547 & 14.0 & 0.9 \\
\hline Chemicals & 6,773 & 3.4 & 29,718 & 5.6 & 17.9 \\
\hline Metal products & 4,995 & 2.5 & 17,157 & 3.2 & 14.7 \\
\hline Optical and science eqpt. & 3,119 & 1.6 & 12,318 & 2.3 & 16.5 \\
\hline Textiles and footwear & 6,906 & 3.5 & 10,520 & 2.0 & 4.8 \\
\hline $\begin{array}{l}\text { Agriculture commodities } \\
\text { of which: }\end{array}$ & 21,892 & 11.1 & 37,421 & 7.0 & 6.1 \\
\hline Palm oil & 3,510 & 1.8 & 19,036 & 3.6 & 20.7 \\
\hline Rubber & 2,282 & 1.2 & 5,787 & 1.1 & 10.9 \\
\hline Sawn timber & 3,039 & 1.5 & 4,051 & 0.8 & 3.2 \\
\hline $\begin{array}{l}\text { Minerals } \\
\text { of which: }\end{array}$ & 12,597 & 6.4 & 52,321 & 9.8 & 17.1 \\
\hline Crude oil & 7,212 & 3.7 & 28,508 & 5.3 & 16.5 \\
\hline Liquefied natural gas & 4,458 & 2.3 & 20,790 & 3.9 & 18.7 \\
\hline Total exports & 196,692 & 100.0 & 533,788 & 100.0 & 11.7 \\
\hline
\end{tabular}

stimulus package, which mainly involves public works projects, is implemented to stabilise the economy during periods of weak external demand. This step could also be taken when the private sector is underperforming. The problem is that public projects may require time to be effective due to problems and delays in land acquisition and the tendering process. Recognising the slow pace of projects taking off, the government has stepped up efforts to improve its delivery system. Payments are to be made soon after the completion of projects.

\section{Export composition}

In fact, the federal government has had budget deficits since the 1998 crisis, but it has narrowed them due to consolidation measures undertaken. According to the Ministry of Finance (2006), the fiscal deficit reached a high of 5.7 per cent of GDP in 1999, but it declined to 3.8 per cent of GDP in 2005, thanks to higher revenue amid moderate spending. The fiscal deficit is estimated to have declined further to 3.5 per cent in 2006, a level that will foster economic growth without imposing strains on the government's budget. The conduct of monetary policy will balance the need to contain inflation, while providing a conducive environment for growth. Interest rates have been close to historical lows to encourage private consumption and investment activities, but had increased recently due to rising inflationary pressures.

With measures taken to reform the banking system, restructure bad debts, contain non-performing loans (NPLs) and instil better credit management practices, banks are now operating on a more solid footing (IMF 2001). Largely due to measures taken during the crisis period, the ratio of NPLs to total loans fell from 13.6 per cent in 1998 to about 5.8 per cent in 2005 (see Table 9). Bank Negara, the central bank, has encouraged bank mergers, and these have largely been market-driven, although the central bank has intervened at times to kick-start the negotiation process and to ensure it proceeds smoothly.

There are rising concerns that the household debt level has been increasing over the years. Although 


\begin{tabular}{|c|c|c|c|c|c|}
\hline \multicolumn{6}{|c|}{ Table 6 Direction of exports } \\
\hline & \multicolumn{2}{|c|}{ Exports (1996) } & \multicolumn{2}{|c|}{ Exports (2005) } & \multirow{2}{*}{$\begin{array}{l}\text { Average } \\
\% \text { growth }\end{array}$} \\
\hline & RM million & $\%$ share & RM million & $\%$ share & \\
\hline ASEAN countries & 55,414 & 28.2 & 139,208 & 26.1 & 10.8 \\
\hline Singapore & 40,289 & 20.5 & 83,333 & 15.6 & 8.4 \\
\hline Thailand & 8,069 & 4.1 & 28,723 & 5.4 & 15.2 \\
\hline Indonesia & 3,065 & 1.6 & 12,580 & 2.4 & 17.0 \\
\hline Philippines & 2,360 & 1.2 & 7,476 & 1.4 & 13.7 \\
\hline Other ASEAN & 1,631 & 0.8 & 7,096 & 1.3 & 17.7 \\
\hline Selected North East Asia & 30,395 & 15.5 & 99,184 & 18.6 & 14.0 \\
\hline China & 4,734 & 2.4 & 35,221 & 6.6 & 25.0 \\
\hline Korea & 5,999 & 3.0 & 17,945 & 3.4 & 12.9 \\
\hline European Union (EU) & 26,984 & 13.7 & 62,629 & 11.7 & 9.8 \\
\hline USA & 35,821 & 18.2 & 105,033 & 19.7 & 12.7 \\
\hline Japan & 26,378 & 13.4 & 49,918 & 9.4 & 7.3 \\
\hline India & 3,033 & 1.5 & 14,972 & 2.8 & 19.4 \\
\hline Australia & 3,059 & 1.6 & 18,042 & 3.4 & 21.8 \\
\hline Rest of the world & 15,608 & 7.9 & 44,801 & 8.4 & 12.4 \\
\hline Total & 196,692 & 100.0 & 533,788 & 100.0 & 11.7 \\
\hline
\end{tabular}

Source Bank Negara Annual Report (1996 and 2005).

not reaching an alarming level yet, housing debt levels, as measured by household loans to GDP, has risen to 61.5 per cent in 2005 from 45.3 per cent in 2000. In 2006 household finance was hit hard by the rise in interest rates, an 18 per cent increase in petrol prices, and a 15 per cent hike in electricity rates, not to mention the rise in water tariff rates. Beginning in January 2007, there will be an increase ranging from 25-60 per cent in toll rates for five highways, which could impact on inflation and dampen consumer sentiment. Due to the rise in the cost of living, a moderation in the economy and modest income growth, the NPL ratio in the household sector could creep up. According to the Bank Negara Annual Report 2005, the NPL ratios for households in 2005 was at 7.5 per cent (2004: 7.6 per cent), while for the business enterprises, the corresponding ratio was 11.2 per cent in 2005 (2004: 13.7 per cent). With the NPL ratios trending much lower in 2005 compared with the 1998 crisis-period, the financial sector is on a better foundation and is more resilient to face a slowdown in growth.

\subsection{High level of reserves}

Malaysia's foreign reserves have increased favourably since the crisis, from US\$25 billion in 1998 to US\$70.5 billion in 2005 (Table 7), reaching US\$86.9 billion in February 2007 (Bank Negara Malaysia, MSB). The latest level of foreign reserves is sufficient to finance 8.1 months of retained imports and is 9.1 times the short-term external debt. The sizeable trade surplus, at 25.4 per cent of GDP in 2005, and continued inflows of FDI, have more than offset outflows and contributed to the rise in foreign reserves since the crisis. Although portfolio flows have been volatile at times, the persistently large trade surpluses have acted as a buffer against reversals in portfolio flows. The accumulation of foreign reserves has stemmed from the favourable trade surplus, but one explanation that also applies to Malaysia is that the level of investment has been reduced significantly relative to savings. This has resulted in a large resource surplus arising from the saving-investment gap (Table 8).

Bank Negara has said little on the actual level of foreign reserves, except to say that reserves are 
Table 7 Balance of payments and foreign reserves

\begin{tabular}{lrrrrrrrrrr}
\hline \% of GDP & $\mathbf{1 9 9 6}$ & $\mathbf{1 9 9 7}$ & $\mathbf{1 9 9 8}$ & $\mathbf{1 9 9 9}$ & $\mathbf{2 0 0 0}$ & $\mathbf{2 0 0 1}$ & $\mathbf{2 0 0 2}$ & $\mathbf{2 0 0 3}$ & $\mathbf{2 0 0 4}$ & $\mathbf{2 0 0 5}$ \\
\hline Goods balance & 4.0 & 3.6 & 24.4 & 28.6 & 23.1 & 20.9 & 19.9 & 24.7 & 23.2 & 25.4 \\
Current account & -4.4 & -5.9 & 13.2 & 15.9 & 9.4 & 8.3 & 8.4 & 12.8 & 12.6 & 15.3 \\
Financial account (net) & 6.9 & 2.0 & 0.7 & -8.4 & -6.9 & -4.4 & -3.3 & -3.1 & 3.7 & -7.5 \\
FDI & 5.0 & 5.1 & 3.0 & 3.1 & 2.0 & 0.3 & 1.4 & 1.1 & 2.2 & 0.8 \\
Non-FDI & 1.9 & -3.1 & -2.3 & -11.5 & -8.9 & -4.7 & -4.7 & -4.1 & 1.6 & -8.2 \\
Overall balance & 2.5 & -3.9 & 13.9 & 7.6 & 2.4 & 3.9 & 5.1 & 9.7 & 16.3 & 7.8 \\
Foreign reserves (US\$ billion) & 27.0 & 20.8 & 25.6 & 30.9 & 29.9 & 29.9 & 33.7 & 44.2 & 66.2 & 70.5 \\
Months of imports & 4.4 & 3.4 & 5.7 & 5.9 & 4.5 & 5.1 & 5.4 & 6.6 & 7.9 & 7.8 \\
As ratio of short-term debt & 2.8 & 1.4 & 2.8 & 5.2 & 6.2 & 4.7 & 3.9 & 5.0 & 5.8 & 5.7
\end{tabular}

Source Department of Statistics, Malaysia.

unencumbered and usable. As with other crisis-hit countries, Malaysia has the tendency to accumulate reserves as a precautionary stance to ward off excessive speculation. Bank Negara is no exception in wanting to increase reserves in the hope of reducing the risk and vulnerability to speculative attacks, namely to serve as an added security measure. There appears to be no optimum level of reserves, if China's or other East Asian countries' experiences are indicative. It seems that the more reserves you have the better.

However, there are some potential costs involved in maintaining a high level of reserves. One way of looking at costs is to compare the returns from reserve management relative to interest payments on external debts. If the reserves are invested in low-yielding assets, while interests on foreign debt are higher, then there will be costs in retaining high reserves. In Malaysia's case, although information is scarce, it is likely that some costs are involved. It is reported that most of the reserves are held in sovereign and quasi-sovereign papers of high investment grade as well as in foreign currency deposits, but detailed data is not available. It is expected that there is a modest cost in view of the negative differential between returns on reserves and debt interest charges. About 78.7 per cent of foreign debt in 2006 was in US dollars, with 11.7 per cent in yen.

The cost of sterilising liquidity in Malaysia's case is still manageable. The interest rates are still relatively low and inflation is under control, and Bank Negara still has the capacity to sterilise excessive inflows and to manage liquidity. The yield for the one-year Bank Negara bill was at 2.52 per cent in 2005, and the five-year Malaysian Government Securities had a yield of 3.73 per cent. The benefits of sterilising appear to outweigh the costs. Allowing too much

\begin{tabular}{|c|c|c|c|c|c|c|c|c|c|c|}
\hline \multicolumn{11}{|c|}{ Table 8 Savings and investment (\% of GDP) } \\
\hline$\%$ of GDP & 1996 & 1997 & 1998 & 1999 & 2000 & 2001 & 2002 & 2003 & 2004 & 2005 \\
\hline Total consumption & 59.9 & 59.3 & 54.3 & 56.5 & 57.6 & 62.5 & 62.0 & 61.0 & 59.2 & 59.4 \\
\hline Gross national savings & 38.9 & 39.1 & 42.2 & 41.2 & 40.1 & 34.9 & 34.8 & 36.5 & 37.3 & 37.0 \\
\hline Gross capital formation & 43.5 & 45.4 & 28.2 & 24.1 & 29.8 & 25.9 & 25.8 & 22.9 & 24.1 & 20.9 \\
\hline Savings-Investment gap & -4.6 & -6.3 & 14.0 & 17.1 & 10.3 & 9.0 & 9.0 & 13.6 & 13.3 & 16.1 \\
\hline \multicolumn{11}{|c|}{ Source Department of Statistics, Malaysia } \\
\hline
\end{tabular}


Table 9 Financial sector and related indicators

\begin{tabular}{lcccccccccc}
\hline & $\mathbf{1 9 9 6}$ & $\mathbf{1 9 9 7}$ & $\mathbf{1 9 9 8}$ & $\mathbf{1 9 9 9}$ & $\mathbf{2 0 0 0}$ & $\mathbf{2 0 0 1}$ & $\mathbf{2 0 0 2}$ & $\mathbf{2 0 0 3}$ & $\mathbf{2 0 0 4}$ & $\mathbf{2 0 0 5}$ \\
\hline RM/US\$ exchange rate & 2.52 & 2.81 & 3.92 & 3.8 & 3.8 & 3.8 & 3.8 & 3.8 & 3.8 & 3.79 \\
Change in CPI \% & 3.3 & 2.7 & 5.3 & 2.8 & 1.6 & 1.4 & 1.8 & 1.2 & 1.4 & 3.0 \\
7-day interbank rate \% & 6.98 & 7.61 & 8.46 & 3.38 & 2.66 & 2.79 & 2.73 & 2.74 & 2.7 & 2.72 \\
3-month FD rate \% & 7.21 & 9.06 & 5.83 & 3.33 & 3.48 & 3.21 & 3.2 & 3.0 & 3.0 & 3.02 \\
Average lending rate \% & 10.12 & 11.51 & 9.72 & 7.75 & 7.46 & 6.67 & 6.51 & 6.11 & 5.98 & 6.12 \\
Bank loan growth \% & 28.6 & 26.6 & -1.7 & -5.3 & 5.4 & 3.9 & 4.6 & 4.8 & 8.5 & 8.6 \\
Loan/GDP ratio \% & 132.1 & 150.6 & 147.2 & 131.4 & 121.3 & 129.3 & 124.9 & 119.9 & 114.2 & 112.7 \\
NPL ratio (3-month) \% & N/A & N/A & 13.6 & 11.0 & 9.7 & 11.5 & 10.2 & 8.9 & 7.5 & 5.8 \\
NPL ratio (6-month) \% & 3.7 & 4.1 & 8.0 & 6.4 & 6.3 & 8.1 & 7.5 & 6.8 & 5.8 & 4.6 \\
RWCR banking sector \% & 10.7 & 10.5 & 11.8 & 12.5 & 12.5 & 13.0 & 13.2 & 13.8 & 14.4 & 13.7 \\
Source Department of Statistics, Malaysia & & & & & & & &
\end{tabular}

liquidity in the system could lead to imprudent lending by banks or even asset price inflation, as seen prior to the crisis. This could also lead to the strengthening of the ringgit at an unfavourable rate that could affect export competitiveness.

Bank Negara does not disclose the composition of foreign reserves to the public. Since most of the trade activities are done in US dollars, it is believed that the main reserve currency is the US dollar. With the US dollar weakening against the euro in late 2006, diversifying the reserve composition to euros or other stable currencies could reduce further losses from currency movements. Weighed down by the large and unsustainable US current account deficit, the US dollar is expected to depreciate further over the medium term. The slower growth in the US economy could pressure the dollar to ease further.

After the lifting of the fixed exchange rate of the ringgit on 21 July 2005 to a managed floating regime, the ringgit has appreciated gradually against the US dollar. The ringgit has strengthened by about 7.0 per cent against the US dollar in 2006. The nominal effective exchange rate (NEER) was quite stable in 2006, inching up by 0.7 per cent. The stronger ringgit was also attributed to renewed foreign interests in the local stock market, as they can simultaneously gain from both the rise in equity prices and a stronger currency. The ringgit is still trailing regional currencies as the latter strengthened even more against the US dollar. Preferably, a gradual appreciation of the ringgit would give time for businesses to adjust to a stronger currency. Although exports might be affected somewhat, cheaper imports of raw inputs and machinery could offset some of the pressures on export prices and domestic inflation.

At the regional level, Malaysia is a member of the Association of South East Asian Nations (ASEAN) and is involved in the Chiang Mai Initiative (CMI) which has set up a 'collective fund' that member countries can seek assistance from. The CMI is intended to address short-term liquidity problems and complements international financial facilities. Malaysia has a financial commitment of US $\$ 300$ million in the move to raise the funds of the ASEAN Swap Arrangement (ASA) to US\$2 billion. However, the amount allocated may not be large enough to handle crises of larger proportions.

\section{The financial sector}

The banking sector has gone through fairly extensive restructuring exercises since the 1998 crisis. Banks are healthier, while the soundness of balance sheets has improved after bad loans were taken over by the special purpose vehicle (SPV), Danaharta. Banks started to lend again after disposing of their NPLs. Created during the turmoil of the crisis, Dahanarta wound-up its operation at the end of 2005, after fulfilling its objective of addressing NPL problems in the banking sector. Danaharta had effectively 
recovered a total of RM30.4 billion, with a recovery rate of 58 per cent of the NPLs acquired.

Altogether, the government's financial restructuring costs through the two SPVs, Danaharta and Danamodal (a recapitalisation agency), amounted to RM12.6 billion or 2.5 per cent of GDP. Banks suffered losses of more than RM10 billion since they had sold their NPLs at a discount. The total costs of bank restructuring to the government and the banks came to about RM23 billion or 5 per cent of GDP, lower than the earlier estimate of 18 per cent of GDP by the IMF.

Financial indicators, in general, point to a more prudent management practice in banking institutions. Credit growth was at a moderate rate of 8.6 per cent in 2005, an improvement from a 3.9 per cent growth in 2001 (Table 9), but slower than the excessive double-digit pace in the pre-crisis years. Loan growth for businesses increased by a modest 3.0 per cent in 2005, due to a cautious business climate and some excess capacity, but household loans grew much faster at 15.1 per cent (Bank Negara Malaysia, MSB). Individuals account for 54.5 per cent of outstanding bank loans, while business enterprises had a share of 40.4 per cent in 2005. Lending activities are supported by sustained economic growth and resilient demand from businesses and households.

The loan quality of the banking sector improved further in 2005 amid sustained economic growth. The NPLs have declined to its lowest levels in 2005 since the Asian crisis, as noted earlier. The loan-loss coverage of the banking system strengthened with the fall in NPL levels and with the adoption of more prudent provisioning policies in the banking sector. The loan-loss coverage ratio of the banking system improved to 59.2 per cent on a three-month basis in 2005, from 54.9 per cent in 2004. Capitalisation levels in the banking system was sustained at healthy levels in 2005, with the risk-weighted capital ratio (RWCR) remaining at 13.1 per cent as at end-2005, higher than the recommended 8.0 per cent by the Bank of International Settlements (BIS). With the inclusion of market risk in the risk-adjusted capital framework, in addition to credit risk, capital positions of the banking institutions are now more reflective of various risks affecting the banking sector.

The banking sector landscape has changed dramatically since the crisis. Mergers and acquisition
(M\&A) among banks are encouraged, and most of the M\&As are largely market driven, with the central bank overseeing the whole process. In early 2006, there were ten domestic banking groups, compared with more than 50 disparate financial institutions, previously. All ten domestic banking groups have completed the rationalisation exercise on schedule before the expiration of the exemptions on stamp duty and real property gains tax in January 2006. By end-2006, the local banking group was down to nine with more mergers. Investment banks emerged from the rationalisation of merchant banks, stockbroking firms and discount houses. The Financial Sector Masterplan (FSMP) prefers liberalisation and deregulation of the financial sector at a gradual phase that will allow domestic banks to adequately prepare for greater competition. Foreign equity ownership in the conventional banking sector is still generally restricted at 30 per cent. Foreign equity limit in Islamic banks has been raised to 49 per cent to encourage participation in this growth area. The policy direction continues to focus on enhancing structural and operational efficiencies of domestic banks. The key suggestions are to increase investment in human capital and promote a customer-oriented culture to support the business models and services which meet customers' needs and demand. Much emphasis has been directed at promoting sound risk management practices and corporate governance standards in the banking industry.

The private banks in Malaysia are mostly marketdriven and are highly profit oriented. However, to encourage finance to areas that are less attractive and more risky, such as agriculture and small and medium-sized enterprises (SMEs), the government has set up specialised banks to cater for these sectors, categorised as Development Financial Institutions (DFIs). The agriculture bank provides financing to agriculture projects that can only generate returns over the longer period. Apart from loans, the SME bank gives additional business advisory services to help SMEs apply better management practices, expand their businesses, and gain access to the export market.

Bank Negara continues to deregulate and liberalise the banking sector at a gradual pace. Measures were undertaken to promote efficiency and competitiveness of the banking industry and to strengthen the resilience of the financial system. Banks were allowed to diversify their investment 
activities into unit trusts and derivatives up to a certain limit. Locally incorporated foreign banks were allowed to establish up to four additional branches within a one year period, starting in 2006. Efforts are also directed at strengthening the effectiveness of surveillance to detect emerging vulnerabilities and weaknesses that undermine financial stability. Bank Negara has come up with some assessments regarding the readiness of banking institutions for Basel II. Four key principles are adopted by Bank Negara as strategies to Basel II implementation (Bank Negara Malaysia 2005). These are as follows:

1 Ensuring that risk management standards among all banking institutions are improved over time.

2 Adoption of a more flexible timeframe that allows for the implementation of capacity building measures, recognising that domestic players are at different levels of sophistication, thus more time should be accorded to institutions intending to adopt the more advanced approaches.

3 Implementation should not be based on regulatory mandate. The adoption of advanced approaches should be supported by strong business justification.

4 Ensuring a more effective supervisory process for the adoption of more advanced approaches. This will be achieved through better supervisory practices to assess internal models and advanced risk management systems.

The adoption of Basel II in Malaysia is in line with the overall direction of policy to promote higher standards of risk management among the Malaysian banks in facing greater competition from liberalisation. However, there are challenges and obstacles to overcome such as getting standardised quality data from banking institutions. This will require an internal set up that can capture the required information.

Since the imposition of capital controls in 1998, which has largely been relaxed over time, the Malaysian currency, the ringgit, still does not have legal tender outside the country. Therefore, the ringgit is still noninternationalised and cannot be traded in offshore markets. The reason for limiting the ringgit to the domestic market was based on the experience during the crisis when offshore trading in Singapore had exacerbated speculative pressures on local financial markets. Stock counters that were previously traded in Singapore were also discontinued as a means to contain external pressures.

Even after switching to a managed float regime in July 2005, the ringgit was still not traded offshore. In March 2007, Bank Negara relaxed some rules on foreign exchange trading to enhance activity and reduce transaction costs in the financial sector. The limit on foreign exchange transactions for local banks has been removed and limits on foreign currency accounts were lifted. The central bank governor has remarked that Malaysia will assess the benefits and risks of ringgit internationalisation, and even proposed partial liberalisation as an option. If offshore ringgit trading is allowed, the currency will be exposed to greater volatility and speculative risks, and monetary policy could be rendered less effective. On the positive side, allowing the market to determine the ringgit's value will bring it closer to its equilibrium value, notwithstanding the occasional overshooting. A more liberalised ringgit will improve Malaysia's image, which was tarnished by having capital controls previously. Given the painful past experience in 1998 and the recent speculative burst on the Thai baht in late 2006, it is likely that Malaysia will take a cautious stance on this issue. Even without offshore ringgit trade, foreign inflows have brightened up in early 2007 and the ringgit has reached a 13-year high recently. Without clear benefits more than offsetting the costs, this could mean that offshore trading of the ringgit will come later rather than sooner.

\section{Capital flows/capital account}

Private flows continue to feature significantly in the capital account. However, due to the persistently sizeable trade surpluses since 1998, the current account continues to record surpluses which more than compensate for occasionally large outflows of private short-term funds. The merchandise balance (or the goods balance) has been in surplus of more than 20 per cent of GNP since 1998 (Table 7). This has provided ample cushion against the more volatile short-term flows. The recent large reversal in portfolio investment flows was seen in late 2005, when large speculative inflows of RM32.0 billion in 2004 were reversed to massive outflows of RM14.2 billion in 2005 when the ringgit did not appreciate as anticipated by investors and financial markets did not perform as well as expected. 
Table 10 Federal government finance (\% of GDP)

\begin{tabular}{lrrrrrrrrrr}
\hline As \% of GDP & $\mathbf{1 9 9 6}$ & $\mathbf{1 9 9 7}$ & $\mathbf{1 9 9 8}$ & $\mathbf{1 9 9 9}$ & $\mathbf{2 0 0 0}$ & $\mathbf{2 0 0 1}$ & $\mathbf{2 0 0 2}$ & $\mathbf{2 0 0 3}$ & $\mathbf{2 0 0 4}$ & $\mathbf{2 0 0 5}$ \\
\hline Revenue & 23.0 & 23.3 & 20.0 & 19.5 & 18.0 & 23.8 & 23.1 & 23.4 & 22.1 & 21.5 \\
Current expenditure & 17.3 & 15.9 & 15.7 & 15.5 & 16.5 & 19.1 & 19.0 & 19.0 & 20.3 & 19.7 \\
Net development expenditure & 5.0 & 5.1 & 6.0 & 7.1 & 7.3 & 10.2 & 9.7 & 9.7 & 6.1 & 5.5 \\
Overall surplus/deficit (-) & 0.7 & 2.4 & -1.8 & -3.2 & -5.7 & -5.5 & -5.6 & -5.3 & -4.3 & -3.8 \\
Source Ministry of Finance, Malaysia (2006/7). & & & & & & & & \\
\hline
\end{tabular}

The larger amount of foreign reserves will generally give a sense of confidence that the country can handle a larger amount of short-term outflows. Relative to short-term external debt, the reserves increased from 5.2 times of short-term external debt in 1999 to 9.0 times in 2006. Another factor that has reduced the risk of a capital-account led crisis is the low share of short-term external debt relative to total external debt, remaining at 23.6 per cent in 2005. Total external debt to GNP ratio stood at a manageable 41.4 per cent in 2005. Moreover, the external debt service ratio, measuring debt servicing as a proportion of exports, has been declining from 6.5 per cent as at end-1998 to 4.7 per cent in 2006. These related trends indicate that the risks of a capital account-led crisis have been very much reduced.

The financial account has been relaxed over time following the implementation of capital controls in 1998. The restrictions on the outflow of local funds have been relaxed further. Unit trust firms can now invest up to 50 per cent of their local assets abroad effective April 2007, up from 30 per cent previously There is less fear that outflows will impact on the foreign reserves due to steady and sizeable export earnings and FDI inflows. More positively, FDI flows were not restricted during the capital control period of the crisis and they remain free of restrictions to move in and out of the country. It is foreseen that Bank Negara will continue to deregulate the flows of local funds to allow them to diversify their investments and try to seek better returns in foreign markets. This will come with some risks since local fund managers are not familiar with foreign markets, but the risks can be reduced by investing through foreigners who are well-informed of their own markets.

\section{Vulnerabilities originating from internal imbalances}

The federal government fiscal deficit reached a high of 5.7 per cent of GDP in 2000 (Table 10). At the height of the crisis, the government embarked on a counter-cyclical fiscal stimulus when the private sector was badly affected. The expansionary fiscal policy stayed on because the private sector needed time to recover. The restructuring that took place in the private sector resulted in decline in investment activities. Flexibility in public spending is still needed to support the economy due to the slow pace in private sector recovery and the sometimes uncertain external demand. The policy is for fiscal consolidation to progress gradually, while maintaining a moderate GDP growth pace. A somewhat worrying concern is that Malaysia's fiscal deficit is larger than that of its neighbours such as Thailand and Indonesia, which have been under stricter IMF conditions.

As far as policy is concerned, the reduction in fiscal deficit will proceed at a pace that will not undermine economic activity. The government will continue to practice prudent financial management, giving more focus to greater efficiency, effectiveness and accountability in public spending. On the back of strong private sector growth and higher oil-related revenues, the active fiscal stimulus is not expected to undermine the budget consolidation efforts. From a high of 5.7 per cent of GDP in 2000, the fiscal deficit of the government is expected to decline gradually to 3.5 per cent in 2006 and 3.4 per cent in 2007, a level that will foster economic growth without imposing strains on the government's budget (Ministry of Finance 2006). The 9th Malaysia Plan (9MP) (Economic Planning Unit 2006) targets public investment of about RM40 billion per year during 2006-2010, with the deficit to be contained at 3.4 per cent. $A$ contentious point is how fiscal revenue 
will perform. Revenue from oil and gas takes a large share of more than 20 per cent and if oil prices fall, the revenue targets may not be met and this will require adjustments in spending plans. An 18 per cent hike in local oil prices in February 2006 was part of the government's effort to reduce its subsidy burden, which is estimated to reach RM15 billion in 2006.

\section{Policy suggestion to reduce vulnerabilities}

The weak spots that beset the Malaysian economy during the Asian crisis have shown improvements after various measures were undertaken including the banking sector reform and corporate restructuring exercises. The fixed exchange rate regime was dismantled in July 2005, and the ringgit is now under managed floating based on a basket of currencies. Capital controls have been relaxed over time and local funds are allowed to move abroad, though only up to a certain limit. The ban on ringgit offshore is likely to stay for a while given the cautious stand of the government in view of the volatility in regional currencies. The uptrend in the stock market in early 2007, driven in part by greater foreign interests, has simultaneously strengthened the ringgit as investors try to profit from both the equity and currency appreciation. The risks of sudden reversals have been mitigated by the larger reserve position.

The GDP growth pace is now at a more moderate level of around 5-6 per cent, reducing concerns of overheating which was a main issue during the crisis The growth rate is more sustainable since it is close to the estimated potential growth path of 6.0-6.5 per cent. Malaysia is unlikely to return to the rapid growth pace of more than 9.0 per cent as in the past, given the constantly changing and more challenging global economic landscape. The increasing global competition is making it more difficult to attract FDI and expand the export market. Moreover, the private sector is investing more cautiously following the restructuring episode after the crisis, and the fiscal deficit is a constraint on government spending.

On the positive side, the current account has continuously recorded surpluses since 1999, and this has contributed to the increase in foreign reserves Although portfolio flows continue to have a significant impact on the capital account of the BoP the large trade surplus helps cushion the outflows. There are structural concerns over the heavy reliance on electronics exports, thus exposing the Malaysian economy to fluctuations in the electronics cycle. The higher oil and gas prices and primary commodities, such as palm oil and rubber, in 2006 have contributed favourably to export revenue, partly acting as a buffer to the changes in electronics demand.

The government is making efforts to diversify the economy further by promoting sectors that have growth potentials such as tourism, bio-tech and Islamic financial services. More importantly, there is greater focus on enhancing human capital with plans to upgrade the quality of education at all levels and to encourage constant retraining of workers. $A$ highpowered investment committee, comprising of ministers and high-ranking officials, has been formed to ensure timely approval of high-impact FDI applications. An implementation agency has been set up to make sure that public projects under the 9MP proceed according to the planned timeframe.

In general, the financial sector has become more resilient following the bank mergers and the restructuring measures, including better risk management practices being put in place. Loan growth has moderated to a more sustainable level, although bank loans are still the main source of funding in the economy. The bond market is stil undergoing further development. The mergers have reduced the number of banks in the system and their capital-base is much larger than before, making them more resilient to crisis. Asset quality has improved, NPLs have been brought down and credit systems have been improved.

Private consumption has been resilient so far, but it may moderate in view of the increase in the living costs arising from the cut in oil subsidy. The fiscal stimulus can only offer a limited cushion to the looming external weaknesses. As a note of caution, there are downside risks to Malaysia's growth prospects. The precarious global imbalance, as reflected by the huge and growing US current account deficit, could force a major slide in the US dollar. In the worst-case scenario, this could lead to a downturn in the US economy and the spill over effects can de-rail China's growth momentum. The softening demand in primary markets such as the USA has partly been compensated by the expansion in secondary markets involving intra-Asian trade. Malaysia has grown less sensitive to the USA and more sensitive to East Asia, especially China, in recent times. 


\section{References}

Bank Negara Malaysia, Monthly Statistical Bulletin, various issues, Kuala Lumpur: BNM

Bank Negara Malaysia (2005) Annual Report, Kuala Lumpur: BNM

Economic Planning Unit (2006) Ninth Malaysia Plan 2006-2010, Kuala Lumpur: Prime Minister's

Department
IMF (2001) Malaysia: From Crisis to Recovery, Washington DC: International Monetary Fund Ministry of Finance (2006) Economic Report 2006/07, September, Kuala Lumpur: Ministry of Finance New Straits Times (14 December 2006) 'RMl1 Billion Rescue Bill for Seven Privatised Projects' 